\title{
Dr. Evandro De Oliveira, Genius and Master of Neurosurgery
}

\author{
Pablo Augusto Rubino ${ }^{1}$ \\ ${ }^{1}$ Hospital El Cruce, Buenos Aires, Argentina \\ Arq Bras Neurocir 2021;40(1):24.
}

"Doctor Evandro" was undoubtedly one of the most influential neurosurgeons of the last half century and marked a milestone in neurosurgery, not just in Brazil, but worldwide. Specifically in Argentina, we can certainly say that he revolutionized neurosurgery in our country.

His impact on Argentine neurosurgery was beyond measure, changing the way in which we tackle microneurosurgery. He was able to transmit his formidable surgical technique, which turned out to be the fruit of the perfect combination between Dr. M. G. Yasargil's microsurgical precepts and Dr. A. Rhoton's applied neuroanatomy. This, in addition to the influence received from two of his mentors, fellow pioneers Drs. Raul Carrea and Charles Drake, led to the genesis of a surgical school that made it to these shores and is meant to last over time. His legacy is not limited to his courses at the Hospital de la Beneficencia Portuguesa (to which more than 500 Argentine neurosurgeons attended over the years) but also to his multiple participations in our scientific meetings, (especially in Neuropinamar, with more than 20 attendances) and lately, in the live surgery courses held at the Hospital El Cruce, where we were fortunate enough to share his exceptional skills and neurosurgical wisdom.

Evandro was the one who best figured out how to transfer the "cold anatomy" of the lab to the challenging arena of real microsurgery, solving complex cases with elegance and safety and setting new standards for what can be achieved in this field. His surgeries were, therefore, the natural consummation of his high scientific knowledge and his devotion for beauty. The result, a true work of art.
Many of us were privileged to learn directly (and indirectly) from him. The most interesting things is that not only did we learn his surgical technique but also his work philosophy. Evandro always highlighted the 4 pillars on which a neurosurgeon must rely on: passion, for everything one does, talent (and he clearly had a very high dose of it), tenacity, to always give everything and the best of himself and courage, to face and solve the complex diseases of our specialty.

There are many words to define Evandro, but there are two that come to my mind first. Since Evandro is a synonym of art, I allow myself to draw a parallel and go back in time almost 500 years to arrive at the figure of Verocchio. In addition to being an outstanding painter and sculptor, Verocchio was the teacher of many other remarkable artists of the Renaissance period such as the great Leonardo Da Vinci. I think history repeats itself here: many years later these two figures meet again in the person of Evandro, as genius and master. I think these two words perfectly sum up what Dr. Evandro was for neurosurgery, and also gifted with a great deal of generosity.

In recognition to his greatness and in eternal gratitude for all that of what his surgical school stands for, we are committed to honor, maintain, and spread his legacy to the next generations of neurosurgeons.

Conflict of Interest

None.
Address for correspondence

Pablo Augusto Rubino, MD,

DOI https://doi.org/

10.1055/s-0041-1730277.

ISSN 0103-5355.
Argentina

(e-mail: parubino@hotmail.com). (c) 2021. Sociedade Brasileira de Neurocirurgia. All rights reserved. This is an open access article published by Thieme under the terms of the Creative Commons Attribution-NonDerivative-NonCommercial-License, permitting copying and reproduction so long as the original work is given appropriate credit. Contents may not be used for commercial purposes, or adapted, remixed, transformed or built upon. (https://creativecommons.org/ licenses/by-nc-nd/4.0/) Thieme Revinter Publicações Ltda., Rua do Matoso 170, Rio de Janeiro, RJ, CEP 20270-135, Brazil 